\title{
The New Taxing Right and Its Scope Limitations: A Theoretical Reflection
}

\author{
Qiang Cai*, Fang $\mathrm{Wu}^{* *}$, Xiaorong $\mathrm{Li}^{* * *}$
}

\begin{abstract}
:
While the Unified Approach reallocates taxing rights to market jurisdictions irrespective of the existence of any physical presence therein, such new taxing rights are subject to various qualifications and carve-outs. Concerns have already been raised that these scope limitations may complicate the reform and lead to double taxation. Ultimately, the issue of the scope limitation boils down to the policy rationale of the new taxing right for which this article submits a narrowly-construed benefit theory as a conceptual basis. Based on this benefit theory and relevant market theories, the authors argue that the scope limitations of the new taxing right should be based on the nature of transactions rather than the nature of products (services). In this way, various carve-outs proposed in the Unified Approach documents can be simplified to one business type, specifically, most of business-to-business (B2B) sales. Accordingly, a positive delineation of in-scope business can be drawn: business-to-consumer (B2C) sales and sales through routine-function intermediaries. Franchise arrangements also accord with the purpose of the new taxing right, however, franchise fees can be dealt with through the provisions of royalties in income tax treaties.
\end{abstract}

Keywords: Unified approach, benefit principle, user participation, significant economic presence, consumer engagement, digitalization of the economy

\section{INTRODUCTION}

Since October 2019, the Organisation for Economic Co-operation and Development (OECD) has developed a Unified Approach (UA) to the nexus and profit allocation rules of taxation over cross-border business income, marking an important step towards the goal of addressing tax challenges arising from the digitalization of the economy. ${ }^{1}$ Compared with the traditional

\footnotetext{
* Lecturer at the University of Aberdeen Law School. E-mail: qiang.cai@abdn.ac.uk.

** Associate professor in Shanghai University of Finance and Economics, College of Business. E-mail: wu.fang@mail.shufe.edu.cn.

*** PhD candidate at Peking University Law School. E-mail: sharron_li@pku.edu.cn.

1 OECD, Secretariat Proposal for a "Unified Approach" under Pillar One, Public Consultation Document 9 Oct. 2019 - 12 Nov. 2019 (OECD Publishing 2019); OECD, Statement by the OECD/G20 Inclusive Framework on BEPS on the Two-Pillar Approach to Address the Tax Challenges Arising from the Digitalization of the Economy, OECD/G20 Base Erosion and Profit Shifting Project 8 (OECD Publishing 2020).
} 
tax rules on cross-border business income, the most revolutionary aspect of the UA concerns its tax concession to market jurisdictions. Specifically, certain taxing rights will be reallocated to market jurisdictions irrespective of the existence within those jurisdictions of any physical presence which, by contrast, is traditionally a key threshold for source taxation. ${ }^{2}$ Moreover, the UA purports to develop a simplified and administrable approach to the new taxing right by adopting a three-tier profit allocation mechanism whereby profit that is attributable to a market jurisdiction is simplified to Amount A, Amount B, and Amount C. ${ }^{3}$

However, concerns have already been raised that the goal of simplifying the application of the new taxing right may be compromised by various scope limitations imposed on the UA. Among others, several business sectors such as agricultural and industrial products are carved out from the UA scope. ${ }^{4}$ A related concern is that the interpretation of these carve-outs may give rise to a soaring volume of disputes should the UA ultimately be approved and implemented by countries. Moreover, a question may also arise as to what the policy rationale is for limiting the UA scope in the first place..$^{5}$ All of these nuisances indicate the need for a more systematic and holistic approach to the understanding of UA and its scope of application. It is true that 'Ultimately, the question of scope is a political question'. ${ }^{6}$ Nevertheless, political consensuses based on principled reasoning can at least achieve a greater degree of legitimacy and acceptability as opposed to, for example, blatant horse-trading. In this connection, this article seeks to holistically and theoretically elucidate the new taxing right and its scope. In particular, an interdisciplinary approach that combines the theories of both taxation and marketing will be employed. The article will be structured as follows.

Section 2 contains an overview of the UA with a focus on the scope of the new taxing right. Section 3 explores the policy rationale for the new taxing right and its scope limitations. Section 4 focuses on analysing several specific issues regarding the limits of the new taxing right. The section ends with recommending a positive delineation - rather than negative carve-outs - of the UA scope. Section 5 concludes.

\section{OVERVIEW OF THE UA AND ITS SCOPE LIMITATIONS}

\subsection{Outline of the UA}

\footnotetext{
2 OECD, Secretariat Proposal for a "Unified Approach" under Pillar One, supra n. 1, at 5, para. 15.

3 See infra s. 2.1.

4 OECD, Secretariat Proposal for a "Unified Approach" under Pillar One, supra n. 1, at 7, para. 20.

5 See infra s. 2.3.

${ }^{6}$ Report by ADE TAX, from OECD, Public Comments Received on the Secretariat Proposal for a "Unified Approach" under Pillar One (15 Nov. 2019) available at

https://www.oecd.org/tax/beps/public-comments-received-on-the-secretariat-proposal-for-a-unified-approach-unde r-pillar-one.htm (accessed 3 Jul. 2020).
} 
The UA was first released in the Secretariat Proposal for a 'Unified Approach' under Pillar One (October 2019, hereinafter the Secretariat Proposal) for seeking comments from the public. Based on the inputs from the public and the follow-up work since the release of the Secretariat Proposal, the OECD/G20 Inclusive Framework on Base Erosion and Profit Shifting (BEPS) (hereinafter Inclusive Framework or IF) endorsed the UA in the Statement by the OECD/G20 Inclusive Framework on BEPS on the Two-Pillar Approach to Address the Tax Challenges Arising from the Digitalization of the Economy (January 2020, hereinafter IF Statement). ${ }^{7}$ According to the UA, three types of profit may be allocated to a market jurisdiction: ${ }^{8}$

Amount A: a share of residual profit allocated to market jurisdictions irrespective of the existence of physical presence within those jurisdictions; ${ }^{9}$

Amount B: a fixed remuneration based on the arm's length principle for baseline distribution and marketing functions that take place in the market jurisdiction; ${ }^{10}$ and

Amount C: any additional profit for in-country functions that exceed the baseline activity covered by Amount B. ${ }^{11}$

It could be considered that, among the above three types of profit allocation, only Amount A epitomizes the new taxing right whereas Amount $\mathrm{B}$ and Amount $\mathrm{C}$ are based on the existing transfer pricing rules with an emphasis on physical presence deployed by multinational enterprises (MNEs) in source states. ${ }^{12}$

\subsection{Scope of the new taxing right}

The scope of Amount A is subject to a number of limitations. First, the application will be limited to MNE groups that meet a certain gross revenue threshold. This is to avoid unnecessary compliance costs for smaller businesses. ${ }^{13}$ Second, it is further required that the business in scope must have developed sustained and significant engagement with a market jurisdiction. According to the UA documents, this engagement requirement largely confines the application of Amount A to two broad sets of businesses: automated digital services and

\footnotetext{
7 OECD, Secretariat Proposal for a "Unified Approach" under Pillar One, supra n. 1; OECD, Statement by the OECD/G20 Inclusive Framework on BEPS on the Two-Pillar Approach to Address the Tax Challenges Arising from the Digitalization of the Economy, supra n. 1, at 4-5, para.1-7.

${ }^{8}$ OECD, Secretariat Proposal for a "Unified Approach" under Pillar One, supra n. 1, at 9, para.30.

${ }^{9}$ Ibid.

${ }^{10}$ Ibid.

11 Ibid.

12 OECD, Statement by the OECD/G20 Inclusive Framework on BEPS on the Two-Pillar Approach to Address the Tax Challenges Arising from the Digitalization of the Economy, supra n. 1, at 8, para. 11.

13 Ibid. at 12, para. 35 .
} 
consumer-facing businesses. ${ }^{14}$ The provision of automated digital services typically involves exploiting data or content contributed by customers/users. Hence, their abilities to engage a foreign market in an active and sustained manner are rather of general applicability. ${ }^{15}$ It follows that for this set of businesses, the mere generation of above-threshold revenue in a market jurisdiction over a period of years is taken in the UA as a sufficient nexus for the jurisdiction to apply the new taxing right. ${ }^{16}$

In contrast, the situation of consumer-facing businesses is more complicated. On the one hand, this type of business is more traditional than digital automated services and, therefore, implies a lower level of digitalization. On the other hand, the growing use of advanced technologies has increasingly enabled these businesses to interact and engage with their customer bases remotely but aggressively. ${ }^{17}$ Accordingly, for consumer-facing businesses, while a revenue threshold will remain to be the primary evidence of the sustained and significant engagement, further 'plus' evidence is warranted, e.g. MNEs' deployment of physical presence in or targeted advertising directed at the market jurisdictions. ${ }^{18}$

Third, the following business sectors or models are regarded as being less likely to engage the consumer base in an active and sustained manner and, therefore, carved out from the scope of Amount A.

- Extractive industries (e.g. extraction of a nation's natural resources), agricultural industries, and businesses of raw material; ${ }^{19}$

- Businesses selling intermediate products and components that are incorporated into a finished product; $;^{20}$ and

- Most of the activities of the financial services sector. ${ }^{21}$

Lastly, several other business types, though tentatively recognized as in-scope businesses, have been highlighted by the UA documents for further consideration. For instance, the Secretariat Proposal submits that further discussion is needed to clarify whether the consumer-facing business includes the supply of goods and services through intermediaries and the use of franchise arrangements. ${ }^{22}$

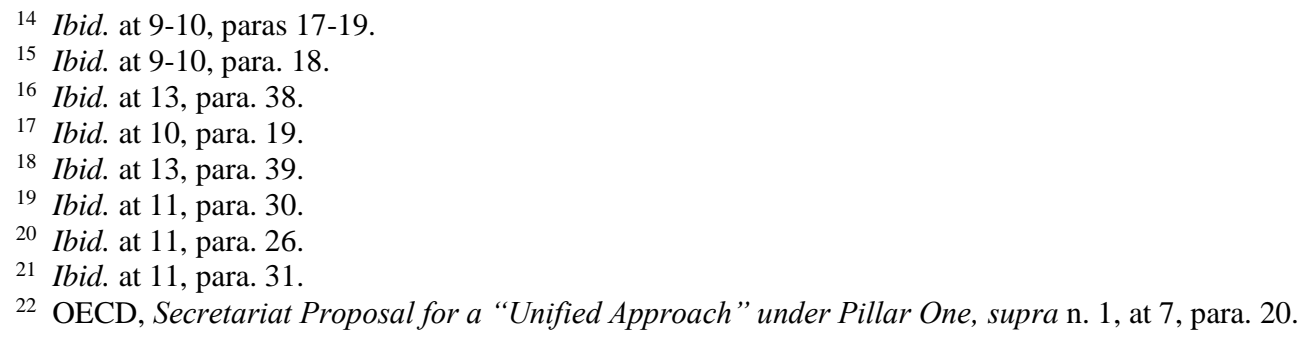




\subsection{Concerns about the scope limitations}

Concerns have already been raised that various limitations on the scope of Amount A may considerably complicate the UA. Indeed, during the consultation process upon the release of the Secretariat Proposal, the vast majority of stakeholders expressed their worries that the application of these scope limitations may become a major source of tax disputes. ${ }^{23}$ Above all is the primary concern related to the ambiguity around the concept of consumer-facing business and consumer engagement. ${ }^{24}$ As the representative from Amazon articulated in their comment, "We consider that a solution that applies to "consumer facing" businesses will be too ambiguous, will create numerous boundary issues and would likely lead to disputes both between taxpayer and tax authority, and between tax authorities themselves. ${ }^{25}$

Several carve-outs of the consumer-facing business are particularly contentious. For instance, many doubted the soundness of the exclusion regarding intermediate products and components, arguing that certain commodities can be sold both as components and as finished products. ${ }^{26}$ Several pharmaceutical companies raised a similar nuisance: while the drugs sold by the companies are doubtlessly consumed by final consumers, they are prescribed by medical institutions and doctors to individual patients. Therefore, it is unclear whether the pharmaceutical industry falls within or beyond the consumer-facing business. ${ }^{27}$

There are also significant calls for the further clarification of the carve-out in relation to sales through intermediaries as multitudes of MNEs may engage in both business-to-business (B2B) and business-to-consumer (B2C) sales. ${ }^{28}$ Sales through B2B channels may also increase the difficulty of tracking the locations of final consumers - after all, the application of the new tax right is conditioned upon the MNE's active and sustained engagement with large consumer bases in a market jurisdiction. ${ }^{29}$

Being aware of the vagueness of the carve-outs, many contend that the new taxing right

\footnotetext{
${ }^{23} \mathrm{OECD}$, Public comments received on the Secretariat Proposal for a 'Unified Approach' under Pillar One, supra n. 6.

${ }^{24}$ For example, see comments from AB Volvo, Accountancy Europe, Business Roundtable, Business Europe, etc. Ibid.

${ }^{25}$ Comments from Amazon, Ibid.

26 See comments from AB Volvo, Afep, etc. Ibid.

27 INSIGHT: Fortune 500 Speak Out on Unified Approach, ICRICT, available at https://www.icrict.com/icrict-in-thenews/2019/12/14/insight-fortune-500-speak-out-on-unified-approach (accessed 23 May 2020).

${ }^{28}$ For example, see comments from ADE Tax, American Chamber of Commerce Iceland, Afep, Business at OECD, etc., OECD, Public comments received on the Secretariat Proposal for a 'Unified Approach' under Pillar One, supra n. 6; See also INSIGHT, supra n. 27.

${ }^{29}$ For example, see comments from ADE Tax, Alliance for Competitive Taxation, etc. OECD, Public comments received on the Secretariat Proposal for a 'Unified Approach' under Pillar One, supra n. 6.
} 
should apply equally to all industries and business models. ${ }^{30}$ More fundamentally, some doubt if there is any merit to limit the UA scope in the first place: if Amount $A$ is to be thought of more in terms of a market access fee, that it should be extended to all businesses that sell into more than one country—not just consumer-facing businesses-and regardless of size of business ${ }^{3}{ }^{31}$

Conversely, some quested whether the carve-outs that are instituted in the UA are sufficiently conclusive. For example, some maintained that the carve-outs should be extended to all B2B transactions. ${ }^{32}$

To be sure, it is not unusual to see various legal principles and rules being subject to numerous exceptions which can be well justified insomuch as they serve legitimate purposes and are structured in a consistent and coherent fashion. The question is that, as one stakeholder points out, without a clear understanding of the policy rationale behind the new taxing right, it would be challenging to judge the appropriateness of excluding certain businesses from the UA scope, particularly considering the ever-evolving business models. ${ }^{33}$

\section{CONCEPTUAL BASIS FOR THE NEW TAXING RIGHT AND ITS SCOPE LIMITATIONS}

\subsection{Overview}

Ultimately, the question about the UA scope culminates into the policy rationale underlying the allocation of taxing rights among countries. Unfortunately, this theoretical aspect has been somewhat overlooked in the UA documents partly because it was built on a preceding saga in which the issue of rationale had already been briefly discussed on several occasions. ${ }^{34}$ Specifically, the UA was based on three immediate predecessors, namely, 'user participation', 'marketing intangibles', and 'significant economic presence' proposals, all of which support some tax concession to market jurisdictions..$^{35}$ Therefore, it is beneficial to make a brief review of the policy rationales for these proposals.

- User participation proposal: the basic idea is that the activities and participation of the

\footnotetext{
${ }^{30}$ See comments from Accountancy Europe, American Chamber of Commerce in Italy, Borioli \& Colombo Associati, etc. Ibid.

${ }^{31}$ INSIGHT, supra n. 27.

32 See comments from American Chamber of Commerce in Belgium, American Chemistry Council, Public comments received on the Secretariat Proposal for a "Unified Approach" under Pillar One, supra n. 6.

${ }^{33}$ Comments from BDO Ibid.

${ }^{34}$ For milestone OECD documents on Action 1, see OECD, Addressing the Tax Challenges of the Digitalisation of the Economy, Public Consultation Document 13 Feb. 2019 - 6 Mar. 2019 (OECD Publishing 2019); OECD, Tax Challenges Arising from Digitalisation, Interim Report (OECD Publishing 2018); OECD, Addressing the Tax Challenges of the Digital Economy, Action 1 Final Report 1 (OECD Publishing 2015).

35 OECD, Secretariat Proposal for a "Unified Approach" under Pillar One, supra n. 1, at 3, para.4.
} 
users in a market jurisdiction contribute to the creation of the brand and the generation of valuable data for a foreign MNE. Therefore, market jurisdictions deserve some taxing rights over in-country businesses carried on by MNEs. The proposal is mainly applicable to automated digital services such as social media platforms, search engines, and online marketplaces. ${ }^{36}$

- Marketing intangibles proposal: this proposal highlights the 'intrinsic link' between the market intangibles developed by MNEs and the market jurisdictions. According to this proposal, a brand name may be reflected in the favourable attitudes in the minds of consumers. Other market intangibles such as customer data and customer relationships are also derived from the activities targeting the customers/users in market jurisdictions. This proposal has the widest scope of application including not only automated digital services but also consumer-facing businesses. ${ }^{37}$

- Significant economic presence proposal: this proposal is motivated by the observation that digitalization has enabled business enterprises to be heavily involved in the economic life of a jurisdiction without any significant physical presence. Based on this rationale, this proposal is mainly focused on businesses through online channels. ${ }^{38}$

The above three proposals all reveal certain types of connection between MNEs and the relevant market jurisdictions in the context of digitalization. Nonetheless, further articulation is needed to establish that such 'connection' justifies the tax concession to market jurisdictions. After all, due to economic globalization and the information revolution, the entire world has been integrated into a 'global village'.

Comparatively, the user participation proposal appears to be more attractive as the value creation principle - i.e. profits should be taxed where value is created - has been enshrined as the bedrock underlying the entire BEPS Project. ${ }^{39}$ Nevertheless, the principle is, at best, a temporary resting place for the inquiry about tax justice as a further query can always be raised about how the process of value creation justifies a taxing right assigned to the place hosting the process. After all, in the business or management world from which tax lawyers borrowed the concept of value creation, those who create value and those who capture it are not necessarily the same. ${ }^{40}$ There are numerous other challenges facing the user participation

\footnotetext{
36 OECD, Addressing the Tax Challenges of the Digitalisation of the Economy (2019), supra n. 34, at 9-10, paras18-19.

37 Ibid. at 11-12, paras 29-32.

38 Ibid. at 16, paras 50, 51.

39 OECD, What is BEPS, available at http://www.oecd.org/tax/beps/about/ (accessed 1 Oct. 2019).

${ }^{40}$ D.P. Lepak, K.G. Smith \& M.S. Taylor, Value Creation and Value Capture: A Multilevel Perspective, 32(1) Academy of Management Review 180, 187-190 (2007).
} 
proposal that will be revisited later. ${ }^{41}$

\subsection{Benefit theory}

\subsection{1 'Quid pro quo'}

The critical review in the above subsection indicates a need for a more fundamental conceptual basis for the allocation of taxing rights among countries. These authors propose a traditional principle in international taxation, namely, the benefit principle, as an ideal candidate for the theoretical construction. This principle provides that taxes should be paid where the business would typically avail itself of the public services provided by the state. ${ }^{42}$ The principle corresponds to the common understanding of taxation in a more general sense, namely, taxes are the price paid by citizens collectively for the public goods provided by a state ${ }^{43}$ More importantly, the principle can be traced to the idea of reciprocity or quid pro quo that is so true and natural to human instinct. ${ }^{44}$

To be sure, the benefit theory was once declined as a proper basis for policy debate and rule design in the early history of international taxation. Specifically, the four economists who were appointed by the League of Nations in the early 1920s to study the issue of double taxation considered that the benefit theory had been supplanted by the theory of ability to pay as a basic principle of taxation. ${ }^{45}$ In contrast, they identified the concept of economic allegiance as a preferable basis to design the international tax framework. Based on this concept, taxes should be paid where businesses develop the greatest degree of economic allegiance. ${ }^{46}$ However, as several contend, the choice between the benefit theory and the theory of ability to pay is mostly a domestic tax issue for which the calculation of tax liabilities and the promotion of individual equity are critically concerned. ${ }^{47}$ Therefore, the theory of ability to pay by no means diminishes the value of benefit theory in the debate in an international tax context. Moreover, the theory of economic allegiance faces the same challenge as with the three proposals discussed above, i.e. the concept cannot be taken as a self-sufficient basis for nexus rules. Indeed, even the four economists occasionally slipped to

\footnotetext{
41 See infra s. 3.2.3.

42 OECD, Addressing the Tax Challenges of the Digital Economy (2015), supra n. 34, at 25-26, para. 32; J. Becker \& J. Englisch, Taxing Where Value Is Created: What's 'User Involvement' Got to Do With It?, 47(2) Intertax, 162 (2020).

${ }^{43}$ K. Vogel, Worldwide vs. Source Taxation of Income-A Review and Re-Evaluation of Arguments (Part III), 11(16) Intertax, 393, 395 (1988).

44 E. Bodenheimer, Jurisprudence: The Philosophy and Method of the Law 232 (Harvard University Press 1981).

45 OECD, Addressing the Tax Challenges of the Digital Economy (2015), supra n. 34, at 24-25, para. 28; 25-26, para. 32.

46 Ibid. at 24-25, para.28.

47 Vogel, supra n. 43, at 395; OECD, Addressing the Tax Challenges of the Digital Economy (2015), supra n. 34, at 26 , para.32.
} 
the benefit account. At one place in their report, they quested: "how, then, should the sum that [the person] finally pays reach these several governments which render him service?"48

\subsubsection{Benefit theory and the taxation of business income}

The benefit theory has been playing an overarching role in the policy debate of international taxation in the past century. ${ }^{49}$ In particular, it is widely believed that the theory shapes the taxing rule over cross-border business income with which the UA is concerned. Specifically, Article 7 (business profits) of the OECD Model Tax Convention on Income and on Capital (OECD Model Convention) provides that a state cannot tax a foreign enterprise on its business income unless the enterprise conducts business via a permanent establishment (PE) situated in the state. ${ }^{50}$ The requirement of a PE as the threshold for source taxation reflects the idea that, as long as a foreign enterprise obtains no benefit of public infrastructure and other public goods from a country, no contribution to the costs of those public goods should be expected from that enterprise. ${ }^{51}$ The problem, however, is that the development of information and communication technologies have enabled firms to carry out large scale businesses in market jurisdictions without the need of deploying a PE or any other type of substantial physical presence therein. In this context, some suggest, with whom these authors concur, that large consumer bases in market jurisdictions also constitute a type of benefit vis-à-vis non-resident enterprises. ${ }^{52}$ Unlike those physical benefits that necessitate a certain degree of geographical proximity between a beneficiary (an enterprise) and a service provider (the host country), consumer bases can be exploited remotely. This particular quality of demand-side benefits justifies the new taxing right reallocated to market jurisdictions without resorting to the existence of physical presence ${ }^{53}$ That being said, the idea of benefit from consumer bases is not free from challenge, not in the least because, traditionally, benefits in tax context primarily refers to public services provided by a government. After all, as mentioned previously, tax is the collective price paid for public goods. In this connection, some propose a custodian account of benefit theory. ${ }^{54}$ Specifically, while it can never be said that the government of a market jurisdiction creates the consumer base, the state can act as a custodian for its own citizens and accordingly tax foreign businesses for their exploitation of

\footnotetext{
${ }^{48}$ League of Nations, Report on Double Taxation: Document E.F.S.73. F.19 18 (1923).

${ }^{49}$ Becker and Englisch, supra n. 42, at 162.

50 OECD Model Conventon (2017), Art.7 (1).

51 K. Holmes, International Tax Policy and Double Tax Treaties: An Introduction to Principles and Application 20-21 (2nd ed., IBFD 2014).

${ }^{52}$ Q. Cai, L. Cerioni \& X. S. Li, New Taxing Right in the Unified Approach: Old Wine in a New Bottle, 48(11) Intertax 962 (2020); Becker and Englisch, supra n. 42, at 170-171.

53 Cai, Cerioni \& Li, supra n. 52, at 962.

54 A. Aslam \& A. Shah, Tec (h) Tonic Shifts: Taxing the "Digital Economy” 23 (International Monetary Fund 2020).
} 
the consumer base situated in the state. ${ }^{55}$ The same logic also applies to the case of natural resources where governments typically hold the resources located within their territories in trust on behalf of their citizens and collect payment for extraction in the form of government revenues. ${ }^{56}$

\subsubsection{Benefit theory in the UA documents}

Indeed, the IF Statement makes several references to the concept of benefit. When justifying the inclusion of automated digital services in the UA scope, the document explains that these businesses 'generally benefit from exploiting powerful customer or user network effects and generate substantial value' and that they 'often benefit from data and content contributions made by users and from the intensive monitoring of users' activities and the exploitation of corresponding data'. ${ }^{57}$ It is worth noting that, while the user participation proposal also places significant emphasis on the ideal of user data, content contribution, and network effect, the proposal and the underlying value creation principle lend little clarification to the policy debate. For example, some contend that the value of digital businesses is indeed created by companies rather than users, and hence the profit concerned should be taxed by the resident countries of those companies instead of market jurisdictions. This is because users generate content or data largely for their own entertainment, and it is those digital companies that mine those data in an entrepreneurial manner. ${ }^{58}$ By contrast, from the benefit perspective, users always lie with the market jurisdictions regardless of the place of value creation.

Another major criticism against the user participation proposal relates to its emphasis on active user contribution. This reflects a postulation that value can only be created in the production process or the supply side rather than the demand side. ${ }^{59}$ The upshot is that the proposal rather 'ring-fences' those highly digital businesses and thus is sometimes dubbed as 'Google Tax'.60 In contrast, from the perspective of the benefit theory, the large consumer bases in market jurisdictions also constitute qualified benefits for tax purposes even though these consumers may not be as active in terms of user contribution as their counterparts consuming automated digital services.

\subsection{Qualification of the benefit theory}

\footnotetext{
55 Ibid. at 23.

56 Ibid. at 23

57 OECD, Statement by the OECD/G20 Inclusive Framework on BEPS on the Two-Pillar Approach to Address the Tax Challenges Arising from the Digitalization of the Economy, supra n. 1, at 9-10, para.18.

58 Becker and Englisch, supra n. 42, at 167-170.

59 M. P. Deveraux \& J. Vella, Taxing the Digitalised Economy: Targeted or System-Wide Reform? 4 British Tax Review 387, 394 (2018).

60 R. Neate, What Is the 'Google Tax'? The Guardian, (29 Sept. 2014), available at https://www.theguardian.com/politics/2014/sep/29/what-is-google-tax-george-osborne (accessed 3 Jul. 2020).
} 
Considering the above strength of the benefit theory, oddities may arise immediately. Now that the theory is so established and meritorious, it seems rather groundless for tax lawyers to make such a fuss about the tax challenges of the digitalization since a market jurisdiction can, by all means, tax foreign exporting companies on the grounds that those companies benefit from its market accesses. Accordingly, the requirement of sustained and significant engagement as a prerequisite for the tax concession to market jurisdictions becomes rather redundant. Going further, it would not be necessary for Article 7 of the OECD Model to condition source taxation upon the existence of a PE in the source state as long as the cross-border business is directed to the source state. Indeed, this broad version of the benefit theory does find support in several recent academic initiatives on the reform of international tax rules, such as the cash flow tax and the destination-based tax. Both initiatives propose assigning the taxing right over business income to countries where consumers reside. ${ }^{61}$

The reality, however, is that most scholars and policymakers are very cautious when recognizing mere market accesses as a qualified nexus for the allocation of taxing rights. Since the early history of international taxation, the greatest importance has been attached to the nexus between business income and the physical places contributing to the production of the income. ${ }^{62}$ As the OECD interim report on the BEPS Action 1 observes, a majority of the countries reject the idea that market access alone provides a sufficient link to create a nexus for tax purposes. ${ }^{63}$

Arguably, this cautious attitude towards the nexus solely based on market access is somehow associated with the ideology of trade liberty that has been so embedded in the mind of theorists and policymakers. ${ }^{64}$ For many of them, taxes solely based on market accesses would amount to an overt restriction on free trade just as with tariffs. In these authors' view, even disregarding this ideological consideration, a well-formulated benefit theory would still reject the creation of tax nexuses solely based on market accesses. This is not to deny the value of market accesses as a benefit for MNEs - they are indeed very essential to the success of international commerce. Nevertheless, both source taxation and the new taxing right for market jurisdictions can be justified only if and when a significant degree of public resources provided by countries is exploited by businesses in an active and sustained manner. Otherwise, the benefit theory will become a theory of hollowness as the entire world in this

\footnotetext{
${ }^{61}$ Deveraux and Vella, supra n. 59, at 404-405.

62 OECD, Addressing the Tax Challenges of the Digital Economy (2015), supra n. 34, at 25, para.30.

63 OECD, Tax Challenges Arising from Digitalisation (2018), supra n. 34, at 172, para.390.

${ }^{64}$ For example, concerns have been raised that the proposal of destination-based taxation may contravene international trade law such as WTO rules. IMF, IMF Policy Paper: Corporate Taxation in The Global Economy 9 (2019).
} 
era of global village has become increasingly interconnected and interdependent. If mere access to a market can create a nexus for tax jurisdiction, perhaps countries that are home to certain strategic resources can also claim a similar type of taxing right over MNEs that have purchased these resources in bulk. In that way, a tax jurisdiction would be expanded almost infinitely, and the international tax system may collapse. By contrast, most countries in the real world tax or collect royalty (or license) fees only from businesses that actively engage in mining their natural resources rather than businesses that merely purchase the resources. This narrowly construed benefit theory justifies the requirement of sustained and significant engagement that qualifies the UA scope. It might be questioned if such consumer engagement is really separable from the benefit of market access. Later in this article, these authors will demonstrate that the distinction between the two is feasible and even observable. ${ }^{65}$

Unfortunately, this threshold element of the benefit theory has seldom been articulated in the past discussions on the theory. Indeed, the Action 1 Final Report avers that, under the benefit theory, benefits 'can be specific or general in nature' ${ }^{66}$ This somehow leads to an impression that mere market accesses also qualify as a sufficient benefit for tax purposes, although this impression contradicts the OECD's own position, as was discussed above. As a result, the mainstream account of the benefit theory delivers a rather contradictory picture. On the one hand, little attention has been paid to the qualifications of the benefit theory. On the other hand, however, treaty practice (e.g. treaty rules on the taxation over business income) and policy proposals (e.g. the user participation proposal) unduly confine the scope of benefits to some physical goods in relation to the supply side of businesses.

\subsection{Consumer engagement: insights from market theories}

The concept of 'consumer engagement', or 'customer engagement', or 'customer brand engagement' has been extensively discussed in the marketing theories particularly since $2010{ }^{67}$ Therefore, marketing theories will be fairly pertinent to the analysis of this article. However, the meaning of the concept is rather multi-faceted probably because the concept has been approached in a variety of contexts. ${ }^{68}$ At its core, customer engagement reflects the idea of customer activism: customers do not just passively consume products and/or services but also interact with their suppliers in a proactive manner. ${ }^{69}$ Earlier discussion of customer

\footnotetext{
${ }^{65}$ See infra s. 4.6.3.

${ }^{66}$ OECD, Addressing the Tax Challenges of the Digital Economy (2015), supra n. 34, at 26, para.32.

${ }^{67}$ K. Żyminkowska, Customer Engagement in Theory and Practice A Marketing Management Perspective 24 (1st ed. 2019, Palgrave Pivot 2019); L. Hollebeek, Exploring Customer Brand Engagement: Definition and Themes, 19(7) Journal of strategic Marketing 555 (2011).

${ }^{68}$ Żyminkowska, supra n. 67, at 24; Hollebeek, supra n. 67.

69 Żyminkowska, supra n. 67, at 1; Hollebeek, supra n. 67, at 555.
} 
activism centers on the phenomenon of value co-creation for which 'consumers become active to help personally improve or design the goods and services of the marketplace for themselves or other customers'.$^{70}$ In this sense, it appears that the concept of consumer engagement echoes the value creation principle that underlies the user participation proposal. Nonetheless, marketing theorists gradually accept a more comprehensive approach to the concept that can be defined as 'the level of a customer's cognitive, emotional and behavioral investment in specific brand interactions'. ${ }^{71}$ Regardless of its various forms, from the enterprise's perspective, consumer engagement serves the purpose of creating and strengthening customer loyalty to specific brands. ${ }^{72}$ In this context, value creation is just a means rather than the end. Based on this broader perspective, it can be inferred that consumer engagement can be created and developed through a variety of ways including, inter alia, advertising, customer-friendly services, promotion, and channels of distribution. Indeed, most branding efforts by companies serve the purpose of fostering such consumer engagement. ${ }^{73}$ To summarize, while consumer engagement is more than mere market accesses in that significant effort of consumer marketing and branding is required, it is nevertheless broader than the concept of value co-creation.

\subsection{Interim conclusion}

This section examines the legal (and moral) rationale for the UA and its scope limitations, arguing that, among different theories, the benefit theory qualifies as an ideal conceptual basis for the UA as well as the entire international tax framework. Unlike the user participation proposal and the PE regime, both of which emphasize the supply side of the business, the benefit theory acknowledges that benefits can exist on both the supply and demand sides. This broader perspective lends support to the reallocation of taxing rights to market jurisdictions independent of the existence of a physical presence in those jurisdictions. That being said, a well-formulated benefit theory rejects the idea that mere market accesses can create a tax nexus. Benefits must be of a significant degree and exploited by businesses in an active and sustained manner. This qualification justifies the engagement requirement in defining the scope of the new taxing right in the UA.

\section{ASSESSING CARVE-OUTS AND BORDER CASES REGARDING THE UA SCOPE}

\footnotetext{
70 Żyminkowska, supra n. 67, at 3.

71 Hollebeek, supra n. 67, at 555.

72 Ibid. at 555.

${ }^{73}$ For the relationship (and their difference) between branding and customer engagement, see Ibid. at 563.
} 


\subsection{Introduction}

As was discussed in Section 2.2, a number of business sectors or models are carved out from the scope of Amount A. In addition, several special business types are highlighted by the UA documents for special consideration. All of these carve-outs and special cases relate to the context of consumer-facing businesses.

\subsection{Carve-out in respect of sales of intermediate products and components}

The UA documents do not clarify the rationale for such industrial products being excluded from the UA scope. Arguably, as long as intermediate products and components are sold from a non-resident MNE to an enterprise and incorporated into the finished products by that purchasing enterprise, it is the latter enterprise rather than the former that engages the final consumers. In particular, products sold by original equipment manufacturers (OEMs) bear no brand of their own. ${ }^{74}$ While it is true that industrial suppliers can, and many times do, engage their immediate business customers through marketing activities, such B2B marketing is more targeted and hence less likely to engage large 'client bases' as opposed to the B2C model. ${ }^{75}$ In addition, it is more difficult for B2B suppliers to exploit their clients who are usually professional buyers. Indeed, like OEMs, a B2B supplier is more likely to be exploited by a client that sells branded finished products. ${ }^{76}$ Last, but not the least, compared with the B2C model, B2B marketing features greater reliance on targeted promotion methods such as discount or customer entertainment. ${ }^{77}$ Such benefits will usually be included in the taxable income of either the purchasing enterprise or its employee who receives the benefits (if they are legitimate benefits instead of bribes), both of which are typically taxpayers who are resident to the market jurisdiction. ${ }^{78}$ It follows that, for sales of industrial commodities, either the non-resident enterprises do not acquire significant benefits from the market jurisdictions, or those jurisdictions can well satisfy their fiscal interests by taxing the domestic purchasing enterprises, or both.

Based on the above reasoning, it can be further argued that the same carve-out can be

\footnotetext{
${ }^{74}$ An original equipment manufacturer (OEM) is traditionally defined as a company for which their goods are used as components in the products of another company which subsequently sells the finished item to users. C. Doyle, A Dictionary of Marketing 67 (4th ed., Oxford University Press 2016).

${ }^{75}$ N. K. Malhotra, C. Uslay \& A. Bayraktar, Relationship Marketing Re-Imagined: Marketing's Inevitable Shift from Exchanges to Value Cocreating Relationships 66-67 (Business Expert Press 2016).

${ }^{76}$ R. M. Cortez \& W. J. Johnston, The Future of B2B Marketing Theory: A Historical and Prospective Analysis, 66 Industrial Marketing Management 90, 90 (2017).

77 Malhotra, Uslay, \& Bayraktar, supra n. 75, at 66-67; Cortez and Johnston, supra n. 76, at 90.

${ }^{78}$ For taxation of employment income regarding gifts from clients, see A. Lymer \& L. Oats, Taxation: Policy and Practice 2019/20 26th Edition 2019161 (Fiscal Publications 2019).
} 
extended to most B2B sales. ${ }^{79}$ For instance, sales from an OEM to its business clients almost certainly should be excluded for the UA purpose even if the commodities that are involved in a transaction per se are finished products without the need for substantial processing by the clients. A related concern is that certain commodities seem to be suited for both B2B and B2C transactions, such as office equipment for general purposes. Some suggest that this type of businesses would be either within or beyond the scope of Amount A depending on the relative portion of B2C and B2B sales. In contrast, others suggest having the UA apply only to its B2C segments. ${ }^{80}$ These authors prefer the second approach since the key issue is about the nature of the transactions rather than the nature of the commodities. Similarly, the sales of pharmaceutical products to the professional medical institutions that are mentioned in Section 2.3 should be regarded as B2B transactions and hence carved out from the UA scope even though most of these products bear the brands of the original manufacturers throughout the entire supply chain up to the final consumers.

\subsection{Carve-out in respect of financial services}

According to the IF Statement, the grounds for carving out financial services are twofold. First, most of the activities of the financial services sector occur with commercial businesses and should therefore be classified as B2B transactions. ${ }^{81}$ This line of reasoning supports the view mentioned above that the grounds for carving out industrial products are associated with the nature of the transactions rather than the products. Second, even for the sector's consumer-facing business lines such as retail banks and insurance, consideration should be given to the fact that market jurisdictions typically impose licensing requirements upon incoming foreign financial enterprises so as to protect local deposit/policy holders. Accordingly, it could be said that the residual profits of non-resident financial companies are largely realized in local consumer markets. ${ }^{82}$ However, as the IF Statement recognizes, there may be retail financial businesses that are not subject to licensing requirements, such as digital peer-to-peer lending platforms that may still be covered by the UA. ${ }^{83}$

\subsection{Special considerations for sales through third-party intermediaries}

\subsubsection{Intermediary sales and the B2B model}

On the surface, it appears that intermediary sales should be carved out from the UA scope

\footnotetext{
${ }^{79}$ Except for sales through non-routine distributors, see infra s. 4.4.2.

${ }^{80}$ INSIGHT, supra n. 27.

${ }^{81}$ OECD, Statement by the OECD/G20 Inclusive Framework on BEPS on the Two-Pillar Approach to Address the Tax Challenges Arising from the Digitalization of the Economy, supra n. 1, at 11, para._31.

82 Ibid. at 11, para._31.

83 Ibid. at 11, para._31.
} 
altogether as, by its definition, sales to third-party intermediaries constitute a typical B2B business model. In particular, if the commodities resold by an intermediary bear the latter's brand, then the manufacturer of the commodities would be nothing but an OEM, and hence the sales can hardly be regarded as a type of consumer-facing business. On other occasions, suppliers may retain their brands throughout the channels of distribution yet impose very little control over the channels - they simply sell the commodities to the intermediaries. In such cases, while the sales made by the suppliers may amount to a type of consumer-facing business, the suppliers can hardly be said to have developed active and significant engagement with the large consumer bases in a market jurisdiction. It is rather the intermediaries who actively engage their local consumers and thereby capture a reasonable portion of the profits generated from such an engagement.

The situation may become more complicated when a supplier wants to control the way in which the intermediaries resell the commodities, as typified in distribution arrangements. In addition to the transfer of ownership as is seen in a sales contract, a typical distribution agreement also stipulates that the intermediary (distributor) accepts certain obligations and restrictions in relation to its advertising and the selling of the products bearing the supplier's brand name. In return, the supplier agrees, for example, to confer the distributor the exclusive rights to sell in the relevant territory ${ }^{84}$ In such cases, the supplier's engagement with the final consumers is strengthened rather than disrupted by hiring a third-party intermediary. That being said, consideration should be given to the fact that those intermediaries are normally remunerated an arm's length reward by their suppliers. In this context, the benefits from the sustained and significant engagement with large customer bases in market jurisdictions are at least partially captured by the intermediary enterprises and thus already subject to the taxation of the market jurisdictions. The situation is reminiscent of the PE rules stipulated in income tax treaties. Specifically, if a non-resident enterprise carries on its businesses in a source state through a dependent agent (DA) - such agents approach local customers on behalf of their principals without bearing substantial business risks - then it is deemed that the enterprise has a dependent agent PE (DAPE) in the source state. It follows that two types of profit will be allocated to the source state: one is the arm's length remuneration of the DA which is typically a resident enterprise in the source state, and the other is some extra profit of the non-resident enterprise that is attributable to the DAPE. However, if the non-resident enterprise conducts its businesses in the source state via an independent agent - such agents are typically the distributors discussed above - then the DAPE will not arise, and only the

${ }^{84}$ A. Mavrikakis et al., Business Law and Practice 2018/2019 879 (College of Law Publishing 2018). 
distributors' profit from such intermediary sales will be subject to source taxation. ${ }^{85}$ Arguably, the policy rationale for this discriminatory treatment between dependent and independent agents is that the former only acts as a tool for its principal and procures a limited portion of the profit whereas the latter conducts its own businesses and is fully remunerated for the entrepreneurial risks that it shoulders.

\subsubsection{Sales through routine-function distributors}

From the above reasoning, it seems that the UA makes a mistake by including sales through third-party intermediaries in its scope. Nonetheless, these authors take the view that the UA does have legitimate grounds to cover a particular set of distribution arrangements for which the distributors 'only perform routine tasks such as minor assembly and packaging' in reselling the commodities. ${ }^{86}$ Such routine-function distributors are indeed reminiscent of DAPEs except for the mere fact that the former bear the business risks in relation to the transfer of the ownership of the commodities. It follows that such distributors would only earn some meager remuneration as opposed to full-fledged distributors and that most of the profits generated from the supply chain would be kept by the non-resident suppliers.

For such in-scope intermediary sales, many raise a practical question as to the identification of the location of final consumers. Imagine the scenario in which such distributors not only resell the goods locally but also to foreign markets, or they further contract with sub-distributors who are either wholesalers or retailers. Then how can it be determined if a non-resident supplier has generated above-threshold revenue from the large consumer base in a particular marketing jurisdiction? In these authors' view, this question may not be as troublesome as first expected. This is because in-scope intermediary sales are confined to arrangements with routine-function distributors, most of which are, arguably, local retailers. Otherwise, if a distributor also exploits foreign markets or further contracts with sub-distributors to promote its sales, it has indeed engaged in entrepreneurial activities (e.g. developing its own channels) and will thus be rewarded 'extraordinarily'.

\subsubsection{Evidence of sustained and significant engagement}

Another question may arise regarding the 'plus' evidence of sustained and significant engagement developed by an MNE since a mere revenue threshold is insufficient for consumer-facing businesses to create UA nexuses. While the UA documents suggest that such

\footnotetext{
85 OECD Model Convention (2017), Arts 5, 7; L. Oats, A. Miller \& E. Mulligan, Principles of International Taxation 247-248, 272-273 (6th ed., Bloomsbury Professional 2017).

86 OECD, Statement by the OECD/G20 Inclusive Framework on BEPS on the Two-Pillar Approach to Address the Tax Challenges Arising from the Digitalization of the Economy, supra n. 1, at 11, para._25.
} 
plus factors can be, for example, the existence of a physical presence of the MNE in the market jurisdiction or targeted advertising directed at those jurisdictions, the search for such evidence may become quite problematic. First, there may be difficulties for tax lawyers to identify if the MNE's advertisements are targeting a specific market jurisdiction. According to recent marketing studies, the digitalization of the economy increases the transparency of marketing activities that do not necessarily need to target any particular market: ${ }^{87}$ 'Online shoppers even in the remotest parts of countries such as China or India know a lot about a global brand's attributes and pricing worldwide, without ever having seen the product in a physical store. ${ }^{8} 8$

As to the existence of a physical presence, an MNE selling their commodities through third-party intermediaries may very likely lack any physical presence in relevant market jurisdictions. Notwithstanding this, these authors take the view that, for in-scope distribution arrangements, things do not need to be so complicated as the very fact that an MNE arranges routine-function distributors to help distribute its commodities to final consumers in itself demonstrates the MNE's active exploitation of the destination market. This is similar to the case of the DAPE where a non-resident enterprise actively exploits the market of a source country using a DA as a tool. Therefore, for in-scope distribution arrangements, the existence of a UA nexus will be deemed once an MNE generates above-threshold revenue from the consumer-facing business carried on in the market jurisdiction. This presumption may be rebutted if, for example, the MNE is able to prove that it makes no extra branding effort at the international level in addition to the distribution arrangements.

\subsection{Carve-out in respect of extractive industries}

According to the UA documents, extractive industries are carved out from the scope of Amount $\mathrm{A}$ for the reason that products such as natural resources and raw materials are usually of a generic character, and the prices of these products are generally determined by their internal characteristics ${ }^{89}$ However, the caveat is that disputes may arise as to whether a certain type of commodity is of generic quality. Consider agriculture, for example, for which, while a significant part of the sector involves unbranded commodities delivered in bulk, attention should be paid to the increasing branding efforts in relation to those niche

\footnotetext{
87 J. Steenkamp, Global Brand Building and Management in the Digital Age, 28(1) Journal of International Marketing 13, 19-20 (2020).

88 Ibid. at 19-20.

${ }^{89}$ OECD, Statement by the OECD/G20 Inclusive Framework on BEPS on the Two-Pillar Approach to Address the Tax Challenges Arising from the Digitalization of the Economy, supra n. 1, at 11, para.30.
} 
agricultural or horticultural products. ${ }^{90}$ The IF Statement attempts to differentiate generic agricultural commodities from non-generic food industries using the example of the coffee industry: 'the sale of sacks of green coffee beans will not be within the scope of the new taxing right, whereas the sale of branded jars of coffee will be'. ${ }^{91}$

However, the proposition appears to have eschewed the fact that myriads of consumers today also purchase branded jars of coffee beans to 'DIY' their coffee. Another example is mineral water sold in bottles with different brands - suppliers of such bottled water often boast that their products are 'purely natural' with minimal human intervention.

Arguably, extractive industries can be better dealt with under the B2B carve-out. If certain types of products are of a generic character, such as raw material, they will normally be transacted either as intermediate products being incorporated into finished products or through wholesale intermediaries; and both channels are carved out from the UA scope. On the contrary, if certain extractive products - e.g. raw coffee beans or mineral water - are sold to consumers directly by the suppliers, then these products will most likely be branded and thus lose their generality.

\subsection{Special considerations for franchises}

\subsubsection{Policy rationale}

The IF Statement tentatively proposes to bring into scope 'businesses that generate revenue from licensing rights over trademarked consumer products and businesses', such as under a franchise model. ${ }^{92}$ Under this model, a franchisor licenses the use of its business model, brand, and the rights to sell its branded products/services to a franchisee, which is also known as a satellite business. In return, the franchisee pays royalties to the franchisor and agrees to comply with certain obligations that are typically set out in a franchise agreement. ${ }^{93}$ Generally, the non-resident franchisor specializes in developing market intangibles - i.e. engaging their consumers remotely - whereas the local franchisee is responsible for physically producing and delivering goods/services to the consumers. The royalties, therefore, reflect the franchisor's profit that is generated from its sustained and significant engagement with the consumer base in the market jurisdiction. Hence, the situation squarely fits the UA purpose.

\footnotetext{
${ }^{90}$ B. Walsh, Marketing Agricultural Products and Services, 56 (Tocal College, NSW DPI 2015).

${ }^{91}$ OECD, Statement by the OECD/G20 Inclusive Framework on BEPS on the Two-Pillar Approach to Address the Tax Challenges Arising from the Digitalization of the Economy, supra n. 1, at 11, para.30.

92 Ibid. at 11, para.27.

93 Doyle, supra n. 74 , at 41.
} 


\subsubsection{Taxation over royalties}

Despite the above reasoning, it should be borne in mind that income over royalties has already been dealt with through the articles of royalty in most income tax treaties. While it is true that Article 12 of the OECD Model assigns the taxing right over royalty exclusively to the state where the beneficial owner of the royalty is a resident, many treaties accord with the counterpart article in the UN Model that permits the source state to withhold part of the cross-border payment of royalties made to non-resident taxpayers. In the latter case, it could also be said, just as with the situation of the financial services sector discussed above, that the residual profits of the non-resident franchisor are largely realized in the market jurisdictions. ${ }^{94}$ Therefore, the new taxing right in the UA with respect to franchise arrangements can be realized by modifying the article of royalty in the existing tax treaties to the effect that royalties in relation to licensing rights over trademarked consumer businesses are exclusively taxed by the source state, typically the state where the trademark is used. It is worth noting that this place-of-use rule has long been established in US treaty practice on taxation over royalties. $^{95}$

\subsubsection{Theoretical insights drawn from the franchise arrangement}

The franchise arrangements shed some intriguing light on the UA and its underlying theory. Specifically, in such arrangements, franchisors usually do not access the markets of source states as far as the consumer-facing goods/services are concerned. It is the local franchisees that provide such commodities to final consumers. Accordingly, the royalties almost purely reflect the franchisors' benefits from their remote yet significant engagement with the large consumer bases in the market jurisdictions - market accesses are irrelevant in this situation. ${ }^{96}$ This means that, for the purpose of the benefit theory, the distinction between the access to a market, on the one hand, and an active and sustained exploitation of large customer/user bases on the other hand is not only theoretically substantial but also practically observable.

\subsection{Comments}

\subsubsection{Grounds for carve-outs: product-based or channel-based?}

On the surface, the UA sets out two types of carve-outs: those based on product (or service) types such as carve-outs in respect of extractive products, industrial goods, and financial

\footnotetext{
94 See supra s. 4.3.

95 R. S. Avi-Yonah, International Tax as International Law: An Analysis of the International Tax Regime 44 (Cambridge University Press 2007).

${ }^{96}$ For simplification, it is assumed that the franchisor do not provide technical assistance, or know-how on manufacturing processes, or any intellectual property other than the trademark to the franchisee.
} 
services; and those based on channel patterns including the carve-out regarding intermediary sales. However, the analysis in this section shows that, ultimately, it is the channel pattern that matters the most in determining whether certain business falls within or beyond the UA scope. This is because the choice of channel strategy by MNEs dictates the choice of branding tactics and the way of allocating profits among channel members, both of which are key factors in determining whether an MNE acquires a significant degree of benefits from a market jurisdiction. ${ }^{97}$ This 'channel thinking' was also recommended by a stakeholder in his feedback on the Secretariat Proposal: 'we do not think that the classification of whether a business is consumer or commercial facing should be based on the type of goods or services sold. Instead, we believe that the scoping should take its outset in the type of transaction in terms transactional party and key value drivers.' 98

\subsubsection{What is left for the UA?}

From the above analysis, it could be derived that most of the B2B sales - except for the sales through routine-function distributors and franchise arrangements (which can be dealt with, however, through the treaty rules over royalties) - should be carved out from the UA scope. Accordingly, there would only be two sets of businesses left within the in-scope consumer-facing business: sales through routine-function distributors and $\mathrm{B} 2 \mathrm{C}$ sales via online channels. For the former set, Section 4.4.3 established that the creation of a UA nexus will be deemed once an MNE meets the revenue threshold since the arrangement with routine-function distributors in itself indicates the MNE's active engagement with the consumer bases in the market jurisdictions. Thus, what remains at issue is whether any plus evidence (in addition to the revenue threshold) is required for B2C sales to create the nexus for the UA purpose. This issue can be illuminated by the significant economic presence proposal as was discussed in Section 3.1. Specifically, for an online B2C business to meet the revenue threshold, the MNE would usually be involved in one or more of the following activities: (1) the maintenance of a website in a local language; (2) responsibility for the final delivery of goods to customers or the provision by the enterprise of other support services such as after-sales services or repairs and maintenance; (3) sustained marketing and sales promotion activities, either online or otherwise to attract customers; (4) billing and collection in local currency or with a local form of payment; and (5) deriving large volumes of digital

\footnotetext{
${ }^{97}$ Channel of distribution is a key component of companies' branding strategies. Rajagopal, Competitive Branding Strategies: Managing Performance in Emerging Markets, 154-157 (1st ed.,, Palgrave Macmillan 2019).

98 AB Volvo in Public comments received on the Secretariat Proposal for a "Unified Approach" under Pillar One, supra n. 6.
} 
contents or other data from the consumer bases. ${ }^{99}$ Therefore, for online B2C sales to exceed the revenue threshold, a certain level of sustained and significant engagement or the 'significant economic presence' would almost be unavoidable. That being said, this presumption can be rebutted in a few circumstances, as in the sales through routine distributors. For example, an MNE may prove that its online sales are mostly realized via its Amazon shop; the fulfillment of the sales contracts (e.g. the delivery of the goods) is also performed by Amazon. Indeed, in the context that Amazon engages in significant marketing activities in order to earn internet traffic for the sellers registered with its online platform in return for the fees from those sellers, this platform company is more like a non-routine distributor. As was discussed in Section 4.4.1, sales through non-routine distributors should be carved out from the UA scope.

\subsubsection{Automated digital services: product-based or channel-based?}

By far, the discussions of scope limitations for the UA purpose has been focused on consumer-facing businesses as apposed to automated digital services that are believed to be intrinsically 'consumer-engaged'. However, the above-mentioned Amazon example may also apply to digital businesses. Consider a provider of digital books or digital music selling its products through an Amazon shop; for the same reason, the sales would not create a UA nexus even if the revenue threshold is satisfied. In these authors' view, automated digital services can also be considered from the perspective of channel thinking. Such businesses are included in the UA scope because of the very fact that they are primarily conducted through online channels. In particular, for digital platforms, their interaction with consumers/users is so salient that a mere revenue threshold will be sufficient for creating nexuses for the UA purpose. For B2C sales of digital goods or services, by contrast, the existence of UA nexuses can only be deemed if the revenue threshold is met. Again, the presumption can be rebutted if, for example, an MNE can prove that its digital goods/services are distributed via a third-party online platform that engages in non-routine marketing activities and imposes a significant portion of fees upon its registered sellers.

\section{CONCLUSION}

This article focuses on the scope limitations of the new taxing right in the UA. The question boils down to the policy rationale for such new taxing rights. These authors argue that a narrowly-construed version of the benefit theory provides a proper conceptual foundation for

\footnotetext{
${ }^{99}$ OECD, Addressing the Tax Challenges of the Digitalisation of the Economy(2019), supra n. 34, at 16, para.51.
} 
the new taxing right and its scope limitation. Based on the benefit theory and marketing theories, it has been further argued that whether certain types of businesses should be carved out from the UA should be determined mainly by the channel strategies adopted by such businesses. More specifically, this article proposes to confine the UA scope to three sets of business: (1) businesses of digital platforms; (2) most of the online B2C sales; and (3) a small part of B2B sales (i.e. consumer-facing businesses conducted through routine-function distributors). For all of these business types, the mere creation of the above threshold revenue by MNEs from the businesses carried on in the market jurisdictions over a period of years would be sufficient either for creating a UA nexus (e.g. for digital platforms) or for tax authorities or courts to deem the existence of such nexuses (e.g. for B2C sales and B2B sales in relation to routine-function distributors). In this way, the issue of the scope of limitation for the UA can be significantly simplified.

The finding should not be surprising that, except for the 'thin' sector regarding the sales through routine-function distributors, the proposed scope for the UA would overlap with the scope of significant economic presence proposal almost entirely. This overlap is reasonable because, after all, the major tax challenge of digitalization regarding tax jurisdiction is, as stated in the significant economic presence proposal, that the use of digital technologies has increasingly enabled MNEs to carry out large scale businesses in market jurisdictions without deploying physical presence or hiring local channels in the markets. 